\title{
Community Activity Center Which Prioritizes Socialization Activity in Kwitang, Central Jakarta
}

\author{
Stanly Manuel ${ }^{1}$ Rudy Trisno ${ }^{1}$ \\ ${ }^{1}$ Department of Architecture, Tarumanagara University, S. Parman No. 1, Jakarta 11440, Indonesia \\ "Corresponding author. Email: rudyt@ft.untar.ac.id
}

\begin{abstract}
Kwitang as one of the busiest and most densely populated areas in Jakarta, as a result, basic human needs that are not met causes the people in the Kwitang area to have a business in front of their homes. However, nowadays people getting to be more individualistic because of their business and routine that sometimes makes them easily forget the importance of their social life and taking care of themselves. That makes the existence of the third becomes a solution for people to escape from their routine and have a better social life. The project is expected to be able to overcome the issue and as a forum for community activities, one of which is to meet basic needs such as social interaction, and programs to implement the characteristics of the region in the form of selling books. The design method as a program application; First, potential and location analysis; Second, site analysis; Third, concepts of proposed activities and building programs; Fourth, the final results of the building project. So that the conclusions obtained in this study are various activities in the form of market redesign and reading parks, as well as other supporting functions that are capable of accommodating community activities and addressing issues to have a better quality of life and be able to unite all creativity and activities to restore the need to socialize among people.
\end{abstract}

Keywords: Third place, Kwitang, Market, Reading Park

\section{INTRODUCTION}

Kwitang is part of Senen sub-district, Central Jakarta. Historically, Kwitang was an area known for selling books, and the types of books traded varied. Since the Central Jakarta government curbed this book trader in 2007, the situation in Kwitang is no longer the same, because selling on the road is a violation. But this did not reduce the number of visitors who came to buy books until now. [1].

Based on observations and data obtained, Kwitang is one of the areas that have a high population density. As the city develops, many people have to try their fortune to get additional income, but who very unfortunate is that of the many residents who come to find work, they do not have special abilities or they do not have clear work goals, many of those open a business at their homes such as homemade foods, Laundry, salons, and others.

As a result, people tend to be more individualistic, the majority of the residents don't want to leave the house without any need or do social interaction between residents [2], and not a few of them also only do a round trip from home (as a first place) to work (as a secondplace) every day because there is no third place as a transition place that can be used together.

The purpose and benefit of this project are to create a community activity center or a third place to be a solution or resolution of issues to the community in the Kwitang area. As well as to accommodate the activities of citizens by bringing together all their creativity and daily activities. The supporting programs are expected to provide mutual relations between communities and their environment, and based on the similarity of people who are not known will certainly unite the differences that exist, then it is expected to be a living area. Also, the planned project considers several aspects of the Sustainable Development Goals and the positive that impacts contributed to the city. Making a living area and implementing the element of selling books as a regional characteristic.

\section{METHODS}

In designing the Third Place required characteristics and several important principles that must be met to have an ideal third place [3], such as: On neutral Ground, can offer the diversity or a neutral place for people to get together and where everyone feels comfortable; Leveller, a place or an inclusive place; Conversation, in the third-place also complete the levelling process, the interaction between people; Accessibility and Accommodation is the third place that is easily accessible and provides the best and most comprehensive service a place where one can go alone; The Regulars, The third place is when the right person is there to be alive and of character; A low profile, a third-place is more likely not to impress people who don't know it yet; The mood is playful, the spirit of having 
fun, the feeling of being accepted is an important element; Home away from home, the third room is built from the community, giving rise to one's sense of community or meeting human needs in the neighborhood.

In principle also need to be considering such as: Irrefutable commonality, where people will choose their community based on the undeniable similarity or lack of community; Locations where people interact, one of the characteristics of a developing community is conversation or interaction; generally low-effort or widely attractive, bringing people in the easiest way to get and help them build routines, and foster a sense of togetherness [3].

In designing public spaces, it is important for a city that creates social space and allows people to gather and be involved in a community, some factors affect public space such as Access \& Linkages, Public space is easy to reach and pass through, visible both from a distance or up close; Comfort \& Image, Whether a space is comfortable and presents itself well, includes comfort, safety, cleanliness; Uses \& Activities, Activities are basic, there are reasons why people visit at these places, and why they keep returning. When people see their neighbors and friends, they can greet each other (sociability). Feeling more comfortable to interact with strangers, and having stronger sense of place to their community [4].

Social activities can be interpreted as activities that require other people [5]. The busyness of every citizen of the city in a high enough tempo can reduce attention to each other. If this is excessive it will lead to indifference or lack of social tolerance or a sense of individualism [6].

In connection with social interactions that occur in public space, dividing outdoor activities in public spaces into three categories: Activities based on daily needs, such as shopping, going to work, going to school and so on; Preferred activities, which are activities that are more free time such as walking; Social activities, which are interactive activities that are related to other people, such as greeting, talking or joint activities or are passive contacts such as listening or seeing others [7].

Interaction activities are routine and occur in public spaces, where everyone can use the space in the same capacity and with their routine. The higher the contact, the livelier the activities of a city and vice versa. The nature of these activities will certainly form a character of interaction space that is not limited as a community activity center but rather a place that has meaning, namely Third place.

Market activity retains the traditional characteristics of the Kwitang area, where buyers and sellers meet and there is a direct bargaining process [8]. The difference between traditional and modern markets is that they tend to pay less attention to socialization in communicating between people because there are no direct sellers and buyers who do transaction [9].

And as a characteristic of the area, the community reading park is a place to foster interest in reading to the community, its nature is more informal and its function consists of learning, entertainment (recreational) facilities to take advantage of free time and get the information needed both on educational and unrelated issues [10]. In the design formed from several approaches, as follows:

a. Forms and Function Run Together, Design concepts that work simultaneously between function and form; can be started from program analysis, or can be started from the concept of shape design. But even though they can work individually, they still have a strong and reciprocal relationship and remain united in architectural projects [11].

b. Cross-Programming Design, a concept that put together two different programs in one zone so that overcoming individualism and causing crowds at the same time so that people can interact with each other [12].

c. Continuity Design, the visual perception related to architecture is the perception of Seeing the continuity of a form so that it is not interrupted in the middle, but rather the whole of the form can be seen from the consistency of the sustainability of the form [13].

As a method for applying the indicators of the above theories, they are described as follows; First, Location and potential analysis; second, site analysis; third, concepts of proposed activities and building programs; fourth, the final results of the building project. The issues are focused on Kwitang, Central Jakarta. By observation and data obtained, Kwitang is one of the most populated areas in central Jakarta and known for the book market. Looking at the potential of the neighbour, especially in Kwitang market as a node that intentionally or accidentally formed by people, potentially create an idea about social interaction activity point (See Figure 1).

\section{RESULTS AND DISCUSSIONS}

\subsection{Location and Potential Analysis}

Kwitang is a sub-district of Senen District (See Figure 1). As in the survey conducted in most of the area is housing with yellow zoning, but used as a place to sell at the zoning (See Figure 2).

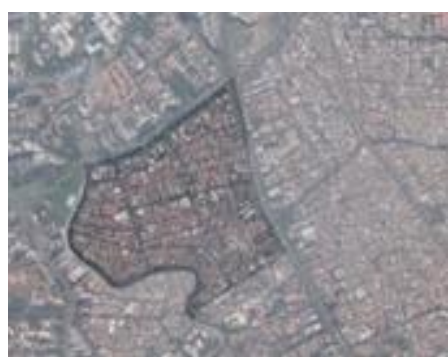

Figure 1 Kwitang Area [14]

On the results and analysis conducted by collecting regional data from characters, problems, and potentials that are in the location of the Kwitang area. Choosing sites based on spatial requirements, being in a location close to the community, walkable distance, and nodes in the form of meeting points that intentionally or unintentionally 
formed in the area are markets in Kwitang that have the potential to realize ideas about encouraging activities so that the area comes alive (See Figure 2).

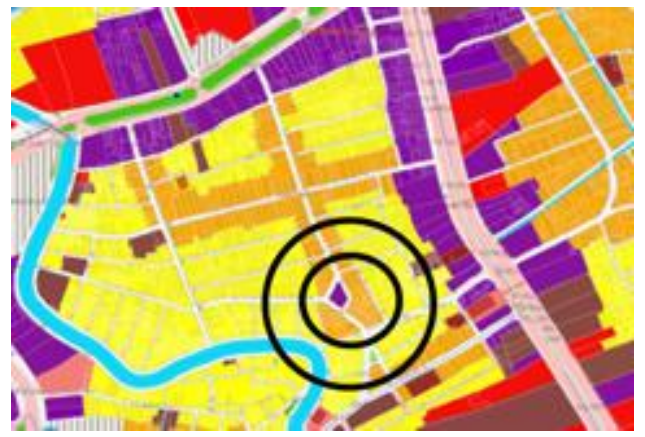

Figure 2 Regional Administration and Nodes [15]

\subsection{Site Analysis}

Land size that stretches over $3200 \mathrm{~m}^{2}$, with Building Coverage Ratio (BCR): 60, Floor Area Ratio (FAR): 2.4, $\mathrm{KB}: 4$, green area: 30 , and coefficient of building heights: 55 [15] (See Figure 3).

Application of the design to the site, by the provisions of the land that is in the mixed zone; the orange colour (See figure 4). While around the site is dominated by 1-2 floors, the west side of the site has a height of 2-3 floors, (See figure 5). So, the massing will bring the flow from west to the east of the site.

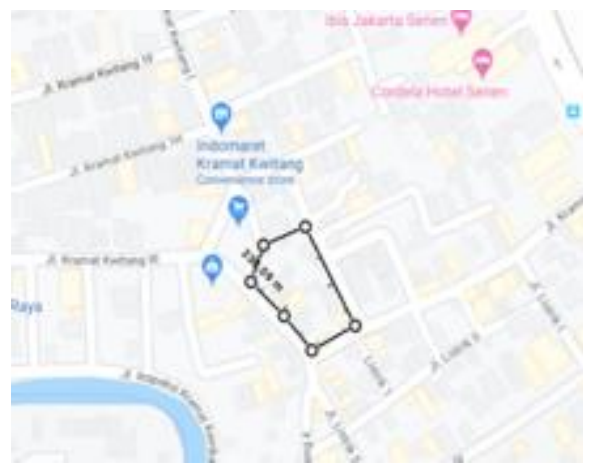

Figure 3 Kwitang Area [14]

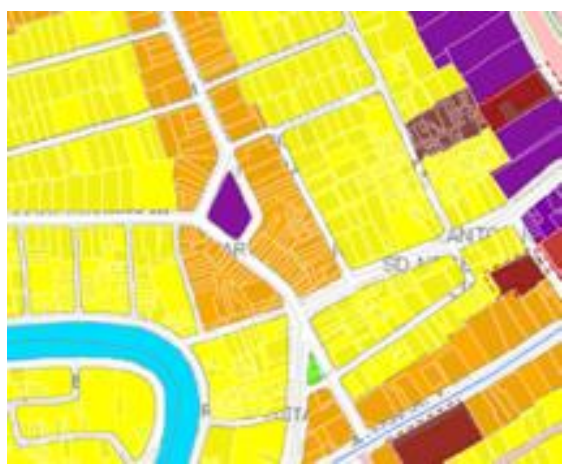

Figure 4 Land Use [15]

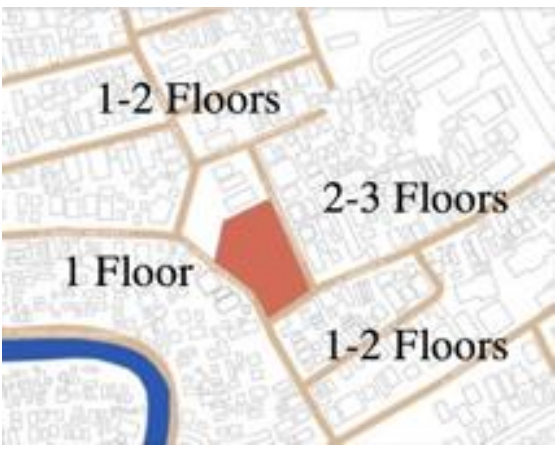

Figure 5 Skyline [14]

\subsection{Concepts of Proposed Activities and Building Programs}

Responds to the problems, needs, and potentials in the environment and even the society are rearranged by combining functions with a Cross-Programming concept. Citizens' activities that are built on the principle that conversation could be possible in a physical place. Then the main program proposed as a unifying community includes market Re-design, reading park, then other programs such as thrifts books, education / workshop, amphitheater, as well as being a green open space in the area. After considering the programs, it can make an area that has a third-place that can accommodate the activities of the Kwitang area, so that they could have a better quality of life and become the character of the region which is the sale of their books and can restore the need to socialize among themselves.

\subsection{The Final Results of the Building Project}

There are 2 concepts of the building, continuity and welcoming space. The concept of continuity used to strengthen access corridor that aims to direct the vision of pedestrians to get around the market, and the concept of welcoming space is to create an open plan and can be accessed from various directions to arrive at a site that prioritizes pedestrian users.

Expressing the shape of the building by the concept of Cross Programming [12], by forming buildings over thinking about building programs together regarding the concept of planning Forms and Function runs together [11]. To strengthen the concept of continuity in the lane, the proposed strengthening of the lane is by making ramp on the market from floor to top floor to strengthen the impression of the continuously (See figure 6).

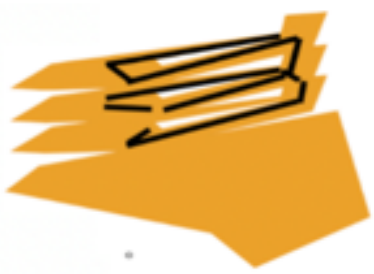

Figure 6 Circulation in the market 
Stairs are given so that visitors can also directly reach the desired floor without passing each ramp on the building, or can also be a ladder during an emergency (See Figure 7). On the 1st floor which is a bookseller; all can be accessed from various directions (See Figure 8). In buildings, every kiosk or shop is modular, can be adapted to the needs of traders (see figure 9).

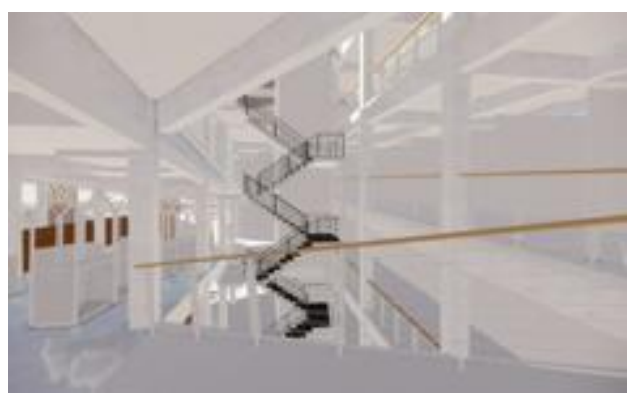

Figure 7 Stairs on each floors

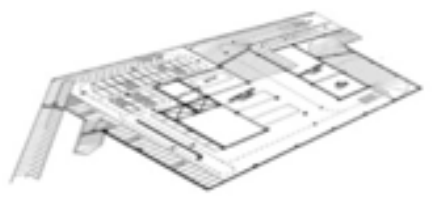

SEMI BASEMENT
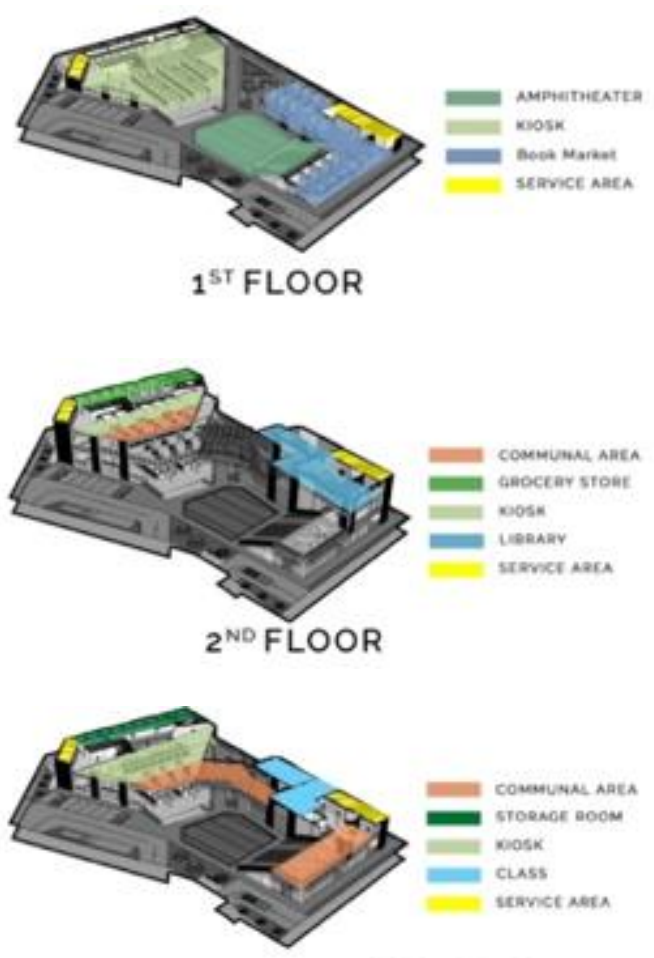

$3^{R D}$ FLOOR

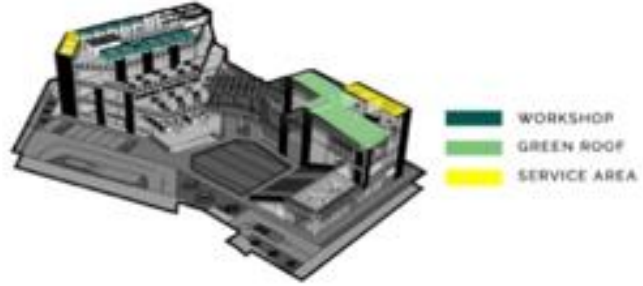

$4^{\text {TH }}$ FLOOR

Figure 8 Zoning

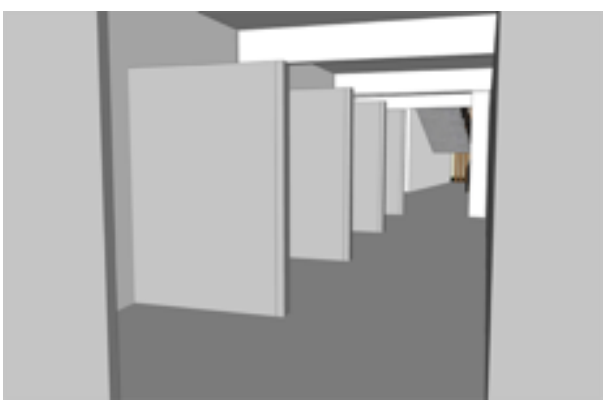

Figure 9 Modular Partition for Book Thrifting

The building is also still in harmony with the environment. In market buildings are open or non-insulated to maximize the potential of light and air that entering the building with cross ventilation.

The building used are using concrete column structures. The structure also does not deviate from the structural norms so that the building can stand and be used. Materials is easy to find such as woods, anti-heat glass for the library, ceramic, natural stone, decking, building facades in the form of hollow galvanized, as well as in buildings not finished by paint to cut costs, as well as vines (Lee Kuan Yew plants) and a green roof to make room green in the region. (See figure 10).
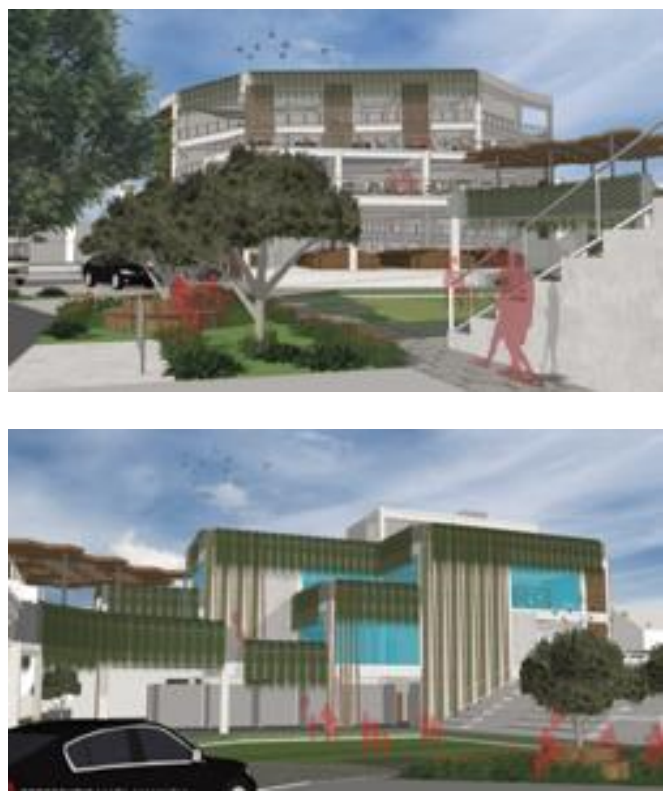

Figure 10 Building Perspectives 


\section{CONCLUSIONS}

The project exists as a third-place designed to resolve the issue of an area to suit the needs and desires of the population, such as returning a sense of needed to socialize with each other. The third-place project underlies the characteristics raised by Ray Oldenburg like: On neutral Ground, Leveller, Conversation, Accessibility and Accommodation, The Regulars, a low profile, Mood is playful, Home away from home, then so becoming an ideal of a third-place.

Site and programs such as market re-design, reading parks, and programs support in the form of book thrifting, amphitheater, workshops, and green open spaces, which are based on consideration in unifying the community. So then in designing, a project be able to accommodate the activities of the community that makes the living area and the community get a better quality of life.

Using cross programming methods, these two different programs combined in one place create a crowd at the same time. Form and Function Run Together method is used to think the building massing while thinking about the concept for the building. Then applying the indicators that described as follows; First, Location and potential analysis; Second, site analysis; The three concepts of proposed activities and building programs; Fourth, the final results of the building project. Therefore, this project and concept could be implemented and be able to overcome the issue in Kwitang area.

\section{ACKNOWLEDGMENT}

Thank you to LPPM-UNTAR (Lembaga Penelitian dan Pengabdian Kepada Masyarakat Universitas Tarumanagara) for funding this research.

\section{REFERENCES}

[1] A. I. Prasetya, "Detik.com," 61 2019. [Online]. Available: https://news.detik.com/berita/d-4372673/ pedagang-buku-di-kwitang-dan-senen-bertahan-di-eraonline. [Accessed 2020].

[2] R. Trisno and F. Lianto, "Realization of Hybrid Concept and Symbiosis in Green Open Space (RTH) at Housing Complex RW (Neighborhood Councils) Pluit, Jakarta Utara, Indonesia," Journal of Physics: Conference Series, pp. 1-6, 2018, Vol 1179.

[3] R. Oldenburg, The Great Good Place: Cafes, Coffee Shops, Bookstores, Bars, Hair Salons, and Other Hangouts at the Heart of a Community, Marlowe \& Company, 1999.
[4] "Project for Public Spaces," [Online]. Available: https://www.pps.org/article/grplacefeat?

[5] Zhang and Lawson, Meeting and Greeting : Activities in public outdoor spaces outside high density urban resindential communities, 2009, pp. 207-214.

[6] R. Bintarto, Interaksi desa-kota dan permasalahannya, Jakarta: Ghalia Indonesia, 1984.

[7] J. Gehl, Life Between Buildings: Using Public Space, Washington: Island Press, 2011, pp. 125-128.

[8] Wikipedia. [Online]. Available: https://id.wikipedia. org/wiki/Pasar_tradisional.

[9] wikipedia, "Wikipedia.org," [Online]. Available: https://id.wikipedia.org/wiki/Pasar.

[10] Dwiyantoro, "Peran Taman Bacaan Masyarakat Mata Aksara dalam menumbuhkan minat baca pada masyarakat," Jurnal Kajian Informasi \& Perpustakaan, vol. 7, 2019.

[11] R. Trisno and F. Lianto, "Relationship Between Function-Form in the Expression of Architectural Creation," pp. 1-6, 392019.

[12] B. Tschumi, "Theory of Contenporary Architecture," [Online]. Available: https://tocapu2017. wordpress.com/2017/10/11/bernard-tschumi/

[13] K. U. S. Sema Uzunoglu, "The application of formal perception of gestalt in architectural," no. 9931003, 2011.

[14] "Google maps," [Online]. Available: https://www. google.com/maps/place/Kwitang,+Senen,+Central+Jak arta+City,+Jakarta/@-6.1828443,106.8357277,16z/data $=! 3 \mathrm{~m} 1$ ! $4 \mathrm{~b} 1 ! 4 \mathrm{~m} 5 ! 3 \mathrm{~m} 4$ !1 s0x2e69f436384819ff:0x9e901f 96482af4cc!8m2!3d-6.1829179!4d106.8406998.

[15] "Jakarta Satu," [Online]. Available: https:// jakartasatu.jakarta.go.id/portal/apps/webappviewer/inde x.html?id=1c1bfcced2cb4852bbeaefcd968a6d04. 